\title{
Iwona Kurz
}

Uniwersytet Warszawski

ORCID: 0000-0001-7180-8670

\section{TEATR I POLITYKA - TEORIA I PRAKTYKA}

Theater and Politics: Theory and Practice 


\begin{abstract}
Abstrakt: Artykuł jest krytycznym omówieniem książki Piotra Dobrowolskiego Teatr i polityka. Dyskursy polityczne w polskiej dramaturgii współczesnej (Poznań 2019). Autor przedstawia w niej ,teksty dla teatru” oraz ich wybrane realizacje sceniczne w Polsce lat 1989-2018. Proponuje syntezę pojęciowo opartą na teorii krytycznej, a przedmiotowo na wyróżnieniu wybranych dyskursów właściwych dla teatru tego czasu - nazywa te całości dyskursywne „dramatem” Innego, historii, kobiety, reprodukcji i gospodarki liberalnej. Książka Dobrowolskiego prowokuje do polemicznych pytań o owocność takiej formy myślenia o polityczności - skoro bowiem ma ono obejmować wszystkie odniesienia do dyskursu epoki, to pytanie o możliwość politycznego oddziaływania teatru się rozmywa. Z kolei arbitralność autorskich wyborów sprawia, że niepewny staje się także status krytycznej syntezy, rozumianej jako ujęcie oferujące perspektywę całościową, ale zarazem uwzględniającą ograniczenia wpisane w syntetyzujące procedury. Istotny kontekst dla analizy (jak i dla samej monografii) stanowią książki: Polityka teatru Pawła Mościckiego, Teatra polskie Dariusza Kosińskiego, a przede wszystkim Demokracja. Przedstawienia Joanny Krakowskiej.
\end{abstract}

Słowa kluczowe: teatr polityczny, polityczność, transformacja, teatr polski 1989-2018

\begin{abstract}
This article offers a critical discussion of Piotr Dobrowolski's book Teatr i polityka. Dyskursy polityczne w polskiej dramaturgii współczesnej [Theater and Politics: Political Discourses in Polish Contemporary Drama] (Poznań 2019), which presents "texts for the theater" and their selected stage productions in Poland between 1989 and 2018. Dobrowolski proposes a synthesis, conceptually based on critical theory and substantively on distinguishing selected discourses specific to the theater of that time. He calls these discursive units the "drama" of the Other, history, woman, reproduction, and the liberal economy. The book provokes polemical interrogations concerning the fruitfulness of such thinking about politicality; for if this line of thought is to cover all references to the discourse of the age, the question about the possibility of theater's political impact loses its contours. The arbitrariness of the author's choices, in turn, undermines the certainty of the critical synthesis, understood as an approach that offers a holistic perspective yet at the same time takes into account the limitations inherent in synthesising procedures. An important context for the reviewer's analysis (as well as for the monograph itself) is provided by Paweł Mościcki’s Polityka teatru [The Politics of Theater], Dariusz Kosiński's Teatra Polskie [Performing Poland], and, above all, Joanna Krakowska's Demokracja. Przedstawienia [Democracy. Performances]. (Trans. Z. Ziemann)
\end{abstract}

Keywords: political theater, politicality, transformation, Polish theater 1989-2018 
Piotr Dobrowolski, Teatr i polityka. Dyskursy polityczne w polskiej dramaturgii wspótczesnej, Wydawnictwo „Poznańskie Studia Polonistyczne”, Poznań 2019

Grudzień 2020. Rocznica wprowadzenia stanu wojennego matematycznym zrządzeniem losu wypadła w niedzielę - już dawno nie ma Teleranka, ale znów na ulicach pojawiła się policja. Każdy protest jest, rzecz jasna, również widowiskiem, ale w tegoroczne, gęste od znaczeń manifestacje wyraźnie wplecione były także motywy metateatralne. Wróciły Mickiewiczowskie Dziady, choć tym razem po to, by dziady wypędzić. Po raz kolejny dyskutowano o rekonstrukcji historycznej - tak część komentatorów postrzega polskie życie polityczne przynajmniej od stycznia 2018, widząc w poprawce do Ustawy o Instytucie Pamięci Narodowej gest założycielski kontynuowanej wciąż rekonstrukcji marca $1968^{1}$.

W tych wydarzeniach uczestniczą ludzie młodzi, uczniowie i uczennice szkół średnich, studentki. Niektórzy mówią: „Wreszcie!”, ale przypomnieć trzeba, że protesty Młodzieżowego Strajku Klimatycznego w marcu i wrześniu 2019 odbyły się w kilkudziesięciu miejscowościach w Polsce. Już wcześniej zatem, choć na mniejszą skalę niż po 22 października 2020, pojawił się w sferze publicznej temat, który nie tylko rozbudził aktywność dużej części młodych, lecz został wręcz ustanowiony przez nich jako nadrzędny cel działania politycznego. Temat ten znalazł odbicie w realizacjach scenicznych. Dziś jednak teatr jest na ulicach oraz w sieci - nie ma go natomiast w budynkach teatrów.

Wydana w 2019 książka Piotra Dobrowolskiego nie może, oczywiście, odnotowywać tych procesów, ale też wcale ich nie zapowiada. Wprawdzie w Dziadach 1968 widzi ważny wzorzec, zatrzymuje się jednak na socjologicznych badaniach wskazujących na konserwatywne postawy młodych ${ }^{2}$. Z tych badań autor wyprowadza wnioski

1 Por. np.: „Dzięki wysiłkom rekonstruktorów udało się zbudować w skali 1:1 makietę Polski sprzed 50 lat”, W. Maziarski, Udana rekonstrukcja marca“68. Rekonstrukcja Gomułki - też, „Gazeta Wyborcza" [online 8 II 2018], https://wyborcza.p1/7,75968,22995886,udana-rekonstrukcja-marca-68rekonstrukcja-gomulki-tez.html [dostęp: 18 XII 2020].

2 P. Dobrowolski, Teatr i polityka. Dyskursy polityczne w polskiej dramaturgii współczesnej, Warszawa 2019, s. 52, http://www.encyklopediateatru.pl/ksiazka/773/teatr-i-polityka-dyskursy-politycznew-polskiej-dramaturgii-wspolczesnej/strona/53 [dostęp: 22 XII 2020]. Lokalizacja kolejnych cytatów w nawiasach kwadratowych w tekście głównym. 
o konieczności ustabilizowania teatralnych form, by ich rozchwierutanie nie przyczyniało się do ogólnego poczucia chaosu, oraz o potrzebie edukacji rozumianej jako podnoszenie kompetencji, zgodnie z pierwszym przykazaniem inteligenta.

Można uznać, że taka - z perspektywy czasu - nietrafiona diagnoza, to cena nie do uniknięcia za pisanie o współczesności w formie monograficznej: współczesność zawsze jest krok dalej lub gdzie indziej. O ile w twórczości publicystycznej czy artykułach można próbować „wąchać swój czas”, jak mawiał aktor, który dał twarz pokoleniu powojennemu, o tyle książka nie może nie być spóźniona. Chyba że przed swój czas wybiegnie.

\section{METODA BEZ METODY}

Najpierw jednak wypada się cofnąć. Puls współczesności bije tu i teraz, ale zwykle pojawia się również pytanie o jej początki. Umowna cezura przyjmowana dla całej formacji historycznokulturowej, w której jesteśmy, to oczywiście rok 1989 - ale dla współczesnego teatru ulega ona przesunięciu, mieszcząc się gdzieś między styczniem 1997 (premiera Bzika tropikalnego Grzegorza Jarzyny i Elektry Krzysztofa Warlikowskiego) a rokiem 2003, kiedy ukazały się antologia dramatu Pokolenie porno (a po niej kilka innych zbiorów) oraz książka Piotra Gruszczyńskiego Ojcobójcy. Po części ta rozbieżność dat jest konsekwencją rozkroku autora Teatru i polityki, który uparcie trwa przy dramacie jako podstawie refleksji, ale zarazem nieustannie chce wkraczać na scenę. $Z$ jednej strony wskazuje bowiem na publikację tomów zbiorowych zawierających dramaty wystawiane w poprzedniej dekadzie czy kilku poprzednich latach; z drugiej wyznacza zwrot postdramatyczny, wiążący się z rezygnacją z gotowego tekstu na rzecz wytwarzania go w procesie współpracy reżysera z dramaturgiem, a potem zespołem aktorskim, w stałym odniesieniu do tego, co poza ścianami teatru.

Różnica $\mathrm{w}$ datowaniu może wydawać się nieistotna, skoro to ledwie kilka lat, a mowa przecież o procesach, w których przypadku daty zawsze są umowne bądź mają charakter sygnałów. Pytajmy zatem o procesy, nie daty. Przedmiotem badania jest okres w sumie trzydziestoletni, ale pierwsza jego dekada - zgodnie z tezą autora - nie była czasem reakcji teatru na współczesność. To notabene temat sam w sobie: dlaczego teatr nie zdołał na żywo i na szybko odpowiedzieć na przemiany transformacyjne (w książce pojawia się tylko krótkie stwierdzenie, że wpłynęły na to istotne problemy instytucjonalne w sferze kultury) i czy rzeczywiście tak szybko odpowiedział na nie dramat. Dobrowolski pisze, że

około roku 2000 zainicjowany został ruch podejmujący próby wspierania autorów dramatycznych i promujący dramat nie tylko jako materiał dla teatru, lecz także jako literaturę posiadającą potencjalną zdolność najżywszego, niemal natychmiastowego reagowania na wyzwania rzeczywistości [s. 67]. 
W przypisie do tego zdania (niejedyny to raz, kiedy ważne i ciekawe kwestie odnotowywane są w przypisach) pojawia się charakterystyka przemiany praktyk teatralnych właśnie w stronę sprzyjającą szybkiemu reagowaniu na rzeczywistość. I tyle. Parę stron dalej wspomniane jest towarzystwo teatralne założone przez Pawła Łysaka i Pawła Wodzińskiego, usytuowane w latach dziewięćdziesiątych (przypomnę, że powołano je w 1998). To symptomatyczne, że ich niezbyt „wyszukany” [s. 74] postulat teatru opisującego rzeczywistość, został sformułowany właśnie wtedy, gdy - dla porównania - premierę miał Dlug Krzysztofa Krauzego, czyli zaangażowany społecznie film stanowiący zwieńczenie nurtu bandyckiego w kinie. Można to uznać za symptom przemiany nastrojów społecznych, kiedy po dekadzie projekcji, fantazji czy, jak pisze Dobrowolski, symulacji przyszedł czas na krytykę i rewizje.

Zwracam uwagę na ten moment, ponieważ dobrze obrazuje on kłopoty z wywodem wynikające $\mathrm{z}$ niedostatecznej gęstości historycznego tła. Konkret daty i konkret kontekstu innego niż teatr jest tu nieobecny lub obecny ogólnikowo, czasem pojawia się w przypisach. Wydarzenia teatralne nie zostają umieszczone ani w kontekście aktualnych wydarzeń politycznych i kulturalnych, ani w polu sporu politycznego w Polsce - by wskazać przynajmniej dwa możliwe sposoby uporządkowania materiału. „Dramat”, który daje tytuł kolejnym częściom problemowym osnutym wokół ważnych tematów debaty politycznej - historia, Inny, wiara, emancypacja kobiet, reprodukcja i liberalna gospodarka - staje się w efekcie dramatem zawieszonym w próżni, a analiza nie wskazuje na to, gdzie działania twórcze mają charakter reaktywny czy doraźny, a gdzie można mówić o głębszych procesach i kształtowaniu nowych dyskursów współczesności.

Autor wybiera problemy, które go interesują, a następie ilustruje je za pomocą wybranych dramatów i/lub ich scenicznej aktualizacji. Ilustracje te mają przeważnie charakter szkiców, nie zaś pogłębionych analiz. Arbitralność wyboru materiału zostaje wprawdzie wskazana jako metoda, wygląda to jednak na niezbyt skuteczny gest asekuracyjny. Deklaracja arbitralności nie wystarczy, by czytelnicy mogli podążyć za autorem. By mu zawierzyć (że przywołam pojęcie, do którego jeszcze wrócę), przydałaby się argumentacja. Dobrowolski pisze:

Zdaję sobie sprawę ze znaczenia tematów pominiętych, wśród których znajdują się między innymi - pozostające pod wpływem dyskursów politycznych - rodzina (stanowiąca obszar szczególnego zainteresowania dramaturgów na przełomie wieków), nieheteronormatywność, ekologia, stosunek do czasów Polski Ludowej czy dziedzictwo Solidarności [s. 14].

Serio? „Pozostające pod wpływem dyskursów politycznych”? Czy historia i polityka historyczna nie wiążą się z PRL? Czy Norymberga to dramat o liberalnej gospodarce, czy właśnie o rozliczeniu z PRL? Dlaczego akurat te problemy są bardziej istotne niż inne dla polityczności teatru ostatnich dekad? Dlaczego i jak autor oddziela kwestie emancypacji kobiet od reprodukcji? Jeśli Inny jest przede 
wszystkim Żydem, to jak ,wyjąć” ten wątek z dyskusji wokół polityki historycznej? Dlaczego właśnie w przywoływanych przedstawieniach (czy też dramatach) widać wybrane problemy lepiej niż w innych? Pytania można mnożyć, przede wszystkim dlatego, że autor w ogóle ich nie podejmuje. Rezygnacja z argumentacji związanej z własnymi wyborami jest słabością Teatru $i$ polityki nie tylko dlatego, że uniemożliwia czytelnikom postępowanie interpretacyjne za autorem (powtórzenie jego eksperymentu myślowego), ale też dlatego, że przekłada się na nieczytelność tytułowego problemu książki, czyli relacji teatru i polityki. Wybory te bowiem również w tym wymiarze nie znajdują autorskiego uzasadnienia.

Trudno w tym kontekście nie przypomnieć książki Joanny Krakowskiej Demokracja. Przedstawienia ${ }^{3}$, wydanej w tym samym 2019 roku, ale znanej już Dobrowolskiemu. Kilkadziesiąt odwołań do tej pracy i projektu „Teatr publiczny. Przedstawienia" dowodzi, jak ważne i kłopotliwe zarazem jest dla Dobrowolskiego to odniesienie. Krakowska analizuje dziewięć przedstawień - można powiedzieć, że wybranych równie arbitralnie; nie bez dezynwoltury projektuje zresztą we wstępie możliwe inne układy tytułów. Wybór swój legitymizuje jednak po części motywami decyzji (żadnych „,wielkich” przedstawień czy nazwisk na przykład), a przede wszystkim obszerną analizą źródeł, kontekstów, recepcji, rewizji i wpływów, dzięki której dowodzi, co i jak ,zadziałało”, a jednocześnie pozostawia ślady pozwalające czytelniczce sprawdzić, czy rzeczywiście. Dodać jednak trzeba, że Teatr i politykę można też przeczytać jako opis tła czy głos chóru dla występów „solistów” (przedstawień) zademonstrowanych w Demokracji. W tym sensie książki Krakowskiej i Dobrowolskiego nie tylko przeglądają się w sobie, ale też uzupełniają.

\section{ZAWIERZENIE I NIEUFNOŚĆ}

Piotr Dobrowolski zaczyna wywód od propozycji teatru jako zawierzenia, przywołując wezwanie wygłaszane przez aktora na scenie Mesjaszy w reżyserii Anety Groszyńskiej: „Uwierzcie mi. Musicie mi uwierzyć” [s. 7]. Z jednej strony wskazuje w ten sposób na umowę estetyczną zawiązywaną przez odbiorców z dziełem: mają nie tyle zanurzyć się w nie, ile zawierzyć sytuacji ze świadomością jej umowności. Z drugiej - przywołuje umowę społeczną właściwą dla innych obszarów życia opartych na zawierzeniu, czyli religii i polityki. Zastanawiając się nad politycznością teatru, nie można jednak pominąć istotnej różnicy: zawierzenie w teatrze polega także na tym, że zgadzamy się na oszustwo bądź tylko iluzję, na ewentualną zdradę i ryzyko związane $\mathrm{z}$ wyprawą $\mathrm{w}$ rejony niebezpiecznych

\footnotetext{
3 J. Krakowska, Demokracja. Przedstawienia, Warszawa 2019.
} 
fantazji i nieznanych wyobrażeń, na uderzenie tego, co niespodziewane, i na stałe krążenie pomiędzy odniesieniem do rzeczywistości a ramą reprezentacji.

To oczywiście nie jest cecha każdego teatru, ale być może teatr polityczny opiera się na tego rodzaju paradoksie: na zgodzie na to, że umowę zawierzenia można zerwać czy naruszyć. Polityczność teatru to przy tym pojęcie kłopotliwe i szerokie. Dobrowolski idzie tutaj tropem Pawła Mościckiego (Polityka teatru, $2008)^{4}$, który w sferze politycznej wyodrębnia trzy wymiary: parapolityki (fasady czy też spektaklu, który odgrywają przed nami politycy), polityki (rozumianej jako przestrzeń sporu pomiędzy odmiennymi wizjami rzeczywistości) i metapolityki (polityczności). Wymiary te w różny sposób aktualizują się $\mathrm{w}$ dziele teatralnym - włączone w tekst i performowane w połączeniu z gestem i obrazem, mogą być częścią opisu świata przedstawionego lub funkcjonować jako postulat, wezwanie czy zadanie dla widzów. Zdarza się też, że aktualizują się bezwiednie (na przykład skandal nie zawsze jest zamierzony, choć często bywa taktyką twórczą lub promocyjną).

Paradoks teatru politycznego, polegający na tym, że zmusza on do opuszczenia „strefy komfortu” i wykorzystuje zawierzenie, by się mu - w dobrej sprawie i wierze - sprzeniewierzyć, znajduje wyraz również w różnicy pomiędzy opisem lub diagnozą a projektem lub prognozą, w napięciu pomiędzy podejściem czysto deskryptywnym (postulatem opisu rzeczywistości politycznej w teatrze) a możliwym podejściem politycznym (postulatem politycznego działania teatru). Różnica ta jest oczywiście płynna, a komplikuje ją jeszcze kwestia języka estetycznego. Paweł Mościcki podkreślał, że teatr świadomie polityczny czy zaangażowany nie musi i nie powinien być teatrem plakatowym, publicystycznym, opartym na utartych formułach. Dramatyczne odniesienie do rzeczywistości również może zakłócać wygodną wizję świata, jeżeli wyraża treści dotąd skrywane lub wręcz wypierane. Sam opis byłby jednak cechą niewystarczającą, skoro stawką teatru politycznego jest proponowanie nowych języków - i to zarówno w sferze idei, jak i estetyki.

Piotr Dobrowolski wszystkie te wymiary uważa za istotne, wszystkie próbuje podejmować. Przeważnie jednak osobie czytającej pozostawia rozpoznanie pozycji, z jakich przygląda się konkretnym tekstom czy przedstawieniom. Dylemat - opis czy projekt, a jeśli opis, to w jakiej mierze sfunkcjonalizowany - dotyczy więc również jego autorskiej perspektywy. Nieczytelność jego stanowiska (nie politycznego, ale metodologicznego) staje się coraz bardziej dotkliwa.

W Teatrze i polityce pojawiają się tropy, które mogłyby stanowić punkt wyjścia do autorskiego, a zarazem bardziej modelowego czy systematycznego ujęcia złożonego układu tekstów kultury, jej instytucji oraz rzeczywistości, o którym mowa

\footnotetext{
4 P. Mościcki, Polityka teatru. Eseje o sztuce angażującej, Warszawa 2008.
} 
w książce. Pierwszy mieściłby się wewnątrz dzieła (spektaklu czy tekstu), a dotyczyłby napięcia pomiędzy odniesieniem do rzeczywistości a wykorzystaniem ramy reprezentacji. Dobrowolski pisze o tym, jakby mimochodem, w związku z Klątwa (2017) Olivera Frljicia, gdzie to napięcie jest bardzo świadomie rozgrywane. Rozwijając ten wątek, można by wyeksponować poszukiwanie propozycji nowych języków, wcale nieoczywiste i wcale nieczęste (jak podkreśla przywołany w przypisie Artur Żmijewski, s. 12). Drugi trop otwiera możliwość ujęcia problemowego. Spektakle, które wywołały skandal, a które Dobrowolski wymienia jako dowód obecności teatru w sferze politycznej (tu chyba: parapolitycznej) - od Shopping and Fucking do Śmierci i dziewczyny [s. 29] - łączy bowiem wyraźnie seks i krzyż. Są to motywy czy tematy zapalne także w innych dziedzinach artystycznych - przede wszystkim w sztukach wizualnych, które również mają moc mobilizowania polityków i opinii publicznej (wbrew tezie Dobrowolskiego o unikatowym w tej sferze oddziaływaniu teatru). Nie sugeruję, że należałoby podążać za skandalami, ale może warto byłoby skupić się na tych zapalnych punktach życia teatralnego, w których ujawnia się i uaktywnia wspólnota afektywna oraz jej wewnętrzne podziały - jak w komentarzu do Klątwy pisze Agata Adamiecka za Sarah Ahmed (przywoływana, oczywiście, w przypisie, s. 191).

Nie jest moją intencją narzucanie perspektywy autorowi książki, raczej wołanie o to, by fragmentaryczne refleksje ułożyć w obraz, niekoniecznie ornament. I żeby ten obraz mówił coś o wspólnocie politycznej, w której działa teatr.

\section{NO DRAMAT PO PROSTU JEST POLSKA ${ }^{5}$}

Jeszcze jeden brak bije bowiem po oczach - właśnie brak Polski. Pisałam już wcześniej o budzącym niedosyt opisie rzeczywistości, do której odnosi się lub miałby się odnosić dramat i teatr w Polsce. Nie zostały odnotowane wspomniane protesty w kontekście sztuk wizualnych, ale też nie ma Wandy Zwinogrodzkiej jako odpowiedzialnej za Scenę Faktu w telewizji, Smoleńsk pojawia się jako temat wybranych dzieł, a nie punkt zwrotny w dziejach społecznej wyobraźni, a faza „stylizacji” historycznej całkowicie pomija dyskurs „małych ojczyzn” żywy w pierwszej połowie lat dziewięćdziesiątych. Przykłady wątków nieobecnych można mnożyć, ale tu chodzi mi o kwestię szerszą, związaną z oprzyrządowaniem teoretycznym.

Jak już wspomniałam, jako matrycę polityczności teatru w Polsce i jego mit założycielski Dobrowolski wskazuje wydarzenia marca 1968 - w tej mierze, w jakiej wpłynęły na nie Dziady Kazimierza Dejmka. Zapewne można znaleźć inne przykła-

${ }^{5}$ Aluzja do książki A. Leszczyńskiego, No dno po prostu jest Polska. Dlaczego Polacy tak bardzo nie lubia swojego kraju i innych Polaków, Warszawa 2017 [red.]. 
dy i inne modele polityczności - czasem zupełnie odmienne, jak choćby ten, który proponowała Reduta w swojej działalności wychowawczej i polonizacyjnej. Problem polega jednak raczej na tym, że chociaż wybór Dziadów pociąga za sobą określone konsekwencje, autor, po przedstawieniu tego ,przypadku”, przestaje się nimi interesować. W największym skrócie: nie widzi on tego, że choć punktem wyjścia jest tu oczywiście tekst dramatyczny, to podlegający jednak szczególnej aktualizacji w kontekście politycznym. Ucho widza słyszy w nim echo wypowiedzi prasowych i ulicznej szeptanki. Co więcej, to tekst, który wyprowadza ludzi na ulicę, więc działanie performatywne i jego analiza polityczna wymagają uwzględnienia także tej części wykonania. I wreszcie, kolejną warstwę problemową stanowi historia tego tekstu i jego realizacji, która jest jednym z argumentów na rzecz tezy Dariusza Kosińskiego o szczególnej roli dramatu i teatru w wyobraźni społecznej Polek i Polaków. Jego Teatra polskie, a także suplement do nich napisany po posmoleńskich manifestacjach na Krakowskim Przedmieściu ${ }^{6}$ ukazują to zjawisko jako radykalny powrót zombie romantyzmu mesjańskiego. A powrót ten można odczytać jako wyraz braku innych języków politycznych.

Sięgając po Dziady, Dobrowolski dostrzegł zatem model teatralnej polityczności, który mógłby być punktem wyjścia refleksji nad jego trwaniem bądź właśnie przemianą, mógłby stać się narzędziem interpretacji. Wybrał jednak inne podejście: odwołanie do wszystkich świętych teorii krytycznej i dekonstrukcji podmiotowości. Są z tym dwa kłopoty. Po pierwsze, wszystkie te działa, nabite we wstępnej części książki, niekoniecznie wypalają w drugiej, a ciało ujarzmione w dyskursie niknie ostatecznie w wywodzie lub pozostaje takie domyślnie. Po drugie, teoria traci walor wyjaśniania, również dlatego, że relacjonowana jest poza polskim kontekstem.

Czy polską nowoczesność - w jej pierwszej fazie, dziewiętnastowiecznej modernizacji, w formie tęsknoty za nowoczesnością jako spełnieniem dziejów czy też w postaci mechanizmów właściwych dla lat dziewięćdziesiątych XX wieku można tłumaczyć jedynie Foucaultem? Przyjmuję raczej, że każda teoria - o największych nawet roszczeniach uniwersalistycznych - powinna być narzędziem do zastosowania w odniesieniu do określonego materiału czy kontekstu historycznego. Pozostając przy autorze Nadzorować i karać, można więc na przykład zadać pytanie, na ile panoptyzm i dyscyplinująca władza ujarzmiania są u nas korygowane $\mathrm{w}$ wyniku długiego trwania modelu familijnego i rozwijania instytucji poza państwem, jako ciałem obcym w istocie. Albo - dlaczego i w wyniku jakich procesów media wizualne nie odegrały w naszej kulturze tak istotnej roli jak na Zachodzie, za to odegrał ją teatr. Nie tylko dyskursy, ale i same procesy dyskursy-

6 D. Kosiński, Teatra polskie. Historie, Warszawa 2010; idem, Teatra polskie. Rok katastrofy, Kraków-Warszawa 2013. 
wizacji mają swoje odmiany lokalne, uwzględnienie tego wymiaru wzmocniłoby więc analizę historyczno-polityczną. Zwłaszcza że przecież mamy takie prace, pisane z bardzo różnych perspektyw - by wspomnieć Tomasza Kozaka, Jana Sowę czy Ewę Thompson.

Trudno nie zgodzić się z Piotrem Dobrowolskim, że „dobrze się myśli dramatem”, choć nawet tu ciągnie do tego, by wstawić „teatr” zamiast dramat. Między innymi dlatego, że otwiera to możliwość, by także „działać teatrem”. Trudno zarazem oprzeć się wrażeniu, że „dobre myślenie” nie da się wyczytać z samej książki. Rezygnując z uzasadnienia własnych wyborów i z wyrazistego stanowiska metodologicznego, autor pozostawia czytelniczkę jedynie z fragmentami opisu. Tytuł i autorskie deklaracje pozwalają przypuszczać, że taki mógł być pierwotny cel książki. Autor jednak bezustannie wkracza na scenę, a często też na ulicę, co prowokuje do podniesienia stawki - i formułowanych tu pytań o możliwy model polityczności teatru i o polityczność wspólnoty, która teatrem i wobec teatru żyje. 